\title{
RANCANG BANGUN SISTEM PENGELOLAAN DATA KULIAH KERJA LAPANG PLUS MEMANFAATKAN FRAMEWORK CODEIGNITER DENGAN MENGGUNAKAN METODE WATERFALL
}

\author{
Junaedy ${ }^{1}$, Abdul Munir $\mathbf{S}^{2}$ \\ 1junaedy@kharisma.ac.id, ${ }^{2}$ abdulmunir@kharisma.ac.id \\ 1,2STMIK KHARISMA Makassar
}

\begin{abstract}
Abstrak
Penelitian ini bertujuan untuk merancang dan membangun suatu sistem untuk pengelolaan data Kuliah Kerja Lapang Plus (KKLP) berbasis web memanfaatkan framework Codelgniter dengan menggunakan metode waterfall. Sistem ini dibuat dengan berbasis web untuk dapat memudahkan berbagai pihak yang terkait dalam mengakses sistem ini. Pemanfaatan framework Codelgniter, yang merupakan salah satu konsep penerapan Model View Controller (MVC) akan memudahkan dalam membangun sistem ini. Penggunaan metode waterfall akan membuat setiap tahapan dalam pembuatan sistem ini menjadi lebih terstruktur. Penelitian ini akan dilakukan dengan mengambil studi kasus pengelolaan KKLP pada kampus STMIK KHARISMA Makassar. Sistem yang selama ini sudah berjalan pada kampus tersebut masih belum menggunakan sistem komputerisasi dengan data digital yang terpusat. Penggunaan komputer hanya terbatas untuk mencetak dokumen-dokumen yang diperlukan dalam prosesnya. Sistem ini nantinya diharapkan dapat menggantikan sistem yang lama sehingga dapat membantu pihak STMIK KHARISMA Makassar dan dapat menjadi referensi buat pihak lain dalam melalukan pengelolaan data KKLP.
\end{abstract}

Kata kunci: Kuliah Kerja Lapang Plus, waterfall, PHP, Codelgniter

\section{Pendahuluan}

Mahasiswa dalam kualitasnya sebagai masyarakyat Indonesia, yang merupakan salah satu faktor penentu keberhasilan pembangunan nasional tersebut, dituntut untuk belajar guna menjadikan dirinya sebagai mahasiswa insan pembangunan, yang dapat membangun dirinya sendiri serta bertanggung jawab atas suksesnya pembangunan nasional Indonesia.

Mahasiswa sebagai aset bangsa merupakan sumberdaya manusia yang produktif dan potensial, serta akan tumbuh dan berkembang sebagai calon-calon pemimpin dimasa mendatang, sehinggah kebijakan pemerintah melalui penerapan kurikulum nasional dan kebijakan pengelolah perguruan tinggi melalui kurikulum lokal yang sinkron lapangan dengan kebutuhan kerja sangat diperlukan dalam rangka penciptaan aset bangsa yang berkualitas.

Mencermati perkembangan dunia kerja yang semakin kompetitif diiringi pula dengan kebutuhan akan sumber daya manusia (SDM) yang handal sehingga rekruitmen tenaga keja pun dilakukan semakin ketat. Hal ini menuntut para produsen tenaga kerja dalam hal ini salah satunya adalah lembaga pendidikan tinggi diharapkan dapat menyediakan tenaga kerja sesuai dengan kebutuhan pasaran kerja. Oleh karna itu, sebelum mahasiswa menyelesaikan studinya, perlu melakukan pengenalan dunia kerja yang sesungguhnya melalui Kuliah Kerja Lapangan Plus (KKLP).[6]

KKLP merupakan salah satu mata kuliah yang wajib di ikuti oleh semua mahasiswa. Melalui KKLP ini mahasiswa dapat memperoleh pengalaman dalam dunia kerja, sebelum mereka terjun langsung ke dunia kerja setelah menyelesaikan pendidikan S1. Salah satu yang menjadi poin penting dalam pelaksanaan KKLP ini adalah pemilihan lokasi pelaksanaan. Agar mahasiswa dapat memperoleh informasi tentang lokasi-lokasi pelaksanaan KKLP yang baik maka pihak kampus paling tidak dapat memberikan rekomendasi tentang lokasi tersebut.

STMIK Kharisma Makassar merupakan salah satu Sekolah Tinggi Management dan Informatika di Makassar. Dalam perkembangannya Kharisma juga di tuntut untuk menghasilkan mahasiswa yang baik dan berpengalaman, karena itu STIMIK Kharisma menjadikan KKLP menjadi sebuah mata kuliah yang wajib. Saat ini pengolahan data KKLP sudah dilakukan secara komputerisasi dengan menggunakan aplikasi pihak ketiga (Office). Walaupun sudah dilakukan secara komputerisasi, tapi belum menjadi satu sistem yang terintegrasi dan terpusat, sehingga menyulitkan dalam melakukan pengolahan datanya. Pengolahan data KKLP dapat meliputi data mahasiswa, data lokasi, usulan lokasi oleh mahasiswa, persuratan, pembekalan, pembagian kelompok, pembimbing, dan ujian. Selain itu, tidak tersedianya layanan informasi tentang lokasi yang dapat menjadi rekomendasi pelaksanaan KKLP untuk mahasiswa juga menjadi salah satu permasalahan yang perlu diatasi. 
Oleh karena itu, penulis ingin melakukan penelitian untuk menghasilkan suatu sistem yang dapat mengelolah data KKLP dengan baik. Sistem yang dibangun nantinya akan berbasis web, dengan database yang terpusat. Web base digunakan agar sistem dapat diakses dimana saja dan kapan saja oleh pihak-pihak yang terkait. Untuk mempermudah dalam membangun sistem yang berbasis web, maka digunakan salah satu fremework, yaitu Codelgniter yang merupakan salah satu framework dengan konsep Model View Controller (MVC). Dalam merancang dan membangun sistem ini akan menggunakan motode waterfall yang merupakan salah satu metodologi dalam membangun atau mengembangkan perangkat lunak.[1]

\section{Metode}

Metode yang akan digunakan dalam penelitian ini adalah metode pengembangan Waterfall. Model pengembangan software yang diperkenalkan oleh Winston Royce pada tahun 70-an ini merupakan model klasik yang sederhana dengan aliran sistem yang linier.[2]

Metode Waterfall adalah suatu proses pengembangan perangkat lunak berurutan, di mana kemajuan dipandang sebagai terus mengalir ke bawah (seperti air terjun) melewati fase-fase perencanaan, pemodelan, implementasi (konstruksi), dan pengujian. Berikut adalah gambar pengembangan perangkat lunak berurutan/ linear:[2]

a. Analisis kebutuhan

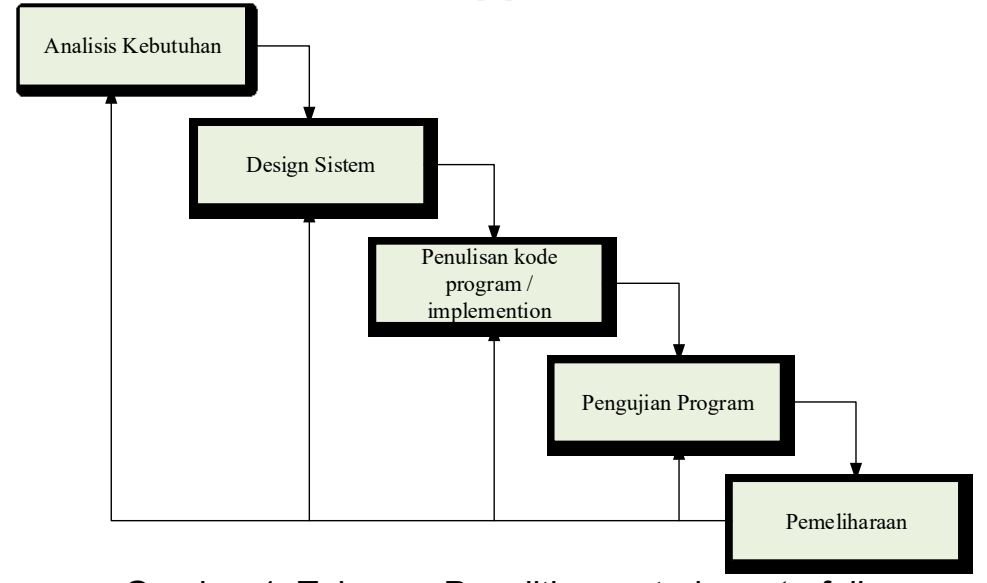

Gambar 1. Tahapan Penelitian metode waterfall

Dalam langakah ini merupakan analisa terhadap kebutuhan sistem. Pengumpulan data dalam tahap ini bisa melakukan sebuah penelitian, wawancara atau study literatur. Seseorang sistem analisis akan menggali informasi sebanyak-banyaknya dari user sehingga akan tercipta sebuah sistem komputer yang bisa melakukan tugas-tugas yang diinginkan oleh user tersebut. Tahapan ini akan menghasilkan dokumen user requirement atau bisa dikatakan sebagai data yang berhubungan dengan keinginan user dalam pembuatan sistem. Dokumen inilah yang akan menjadi acuan ssstem analisis untuk menterjemahkan kedalam bahasa pemrograman.

b. Desain sistem

Proses desain akan menterjemahkan syarat kebutuhan kesebuah perancangan perangkat lunak yang dapat diperkirakan sebelum dibuat koding. Proses ini berfokus pada : struktur data, arsitektur perangkat lunak, representasi interface, dan detail (algoritma) prosedural. Tahapan ini akan menghasilkan dokumen yang disebut software requirement. Dokumen inilah yang akan digunakan programmer untuk melakukan aktivitas pembuatan sistemnya.

c. Penulisan kode program / implemention

Koding merupakan penerjemahan design dalam bahasa yang bisa dikenali oleh komputer.Dilakukan oleh programmer yang akan meterjemahkan transaksi yang diminta oleh user. Tahapan inilah yang merupakan tahapan secara nyata dalam mengerjakan suatu sistem. Dalam artian penggunaan komputer akan dimaksimalkan dalam tahapan ini.

Dalam tahapan ini bahasa pemrograman yang akan digunakan adalah PHP dengan framework Codelgniter. Penggunaan framework Codelgniter akan membuat pembuatan program menjadi lebih terstruktur.

d. Penerapan / Pengujian Program

Tahapan ini bisa dikatakan final dalam pembuatan sebuah sistem. Setelah melakukan analisa, design dan pengkodean maka sistem yang sudah jadikan digunakan oleh user.

e. Pemeliharaan 
Perangkat lunak yang yang telah dibuat terkadang susah untuk dihapami oleh pengguna, sehingga perlu mengalami perubahan. Perubahan tersebut bisa karena mengalami kesalahan karena perangkat lunak harus menyesuaikan dengan lingkungan (periperal atau sistem operasi baru) baru, atau karena pelanggan membutuhkan perkembangan fungsional.

\section{Hasil dan Pembahasan}

Dari penelitian ini penulis mendapatkan beberapa kelemahan dari sistem lama yang digunakan untuk menangani proses KKLP pada STMIK KHARISMA yaitu:

- Pencetakan surat usulan tempat KKLP mahasiswa masih dilakukan dengan cara manual.

- Persetujuan pengajuan tempat KKLP masih dilakukan dengan manual tanpa menggunakan sistem.

- Tidak ada saran tempat KKLP bagi mahasiswa

- Tempat KKLP yang diajukan tidak memberikan pekerjaan sesuai dengan bidang mahasiswa.

- Terlambatnya keluar surat keterangan KKLP.

- Kurangnya kerja sama anatara kampus dan tempat KKLP.

- Belum tersedianya fitur yang dapat mengelola lokasi KKLP pada Sistem Informasi Akademik STMIK KHARISMA.

Dari kelemahan fitur yang telah ada, penulis memberikan beberapa solusi yang mungkin dapat menyelesaikan masalah tersebut, diantaranya:

- Pencetakan surat usulan dilkukan secara online yang memungkinkan mahasiswa dapat mencetak surat usulan dimana saja dan kapan saja.

- Persetujuan lokasi KKLP dilakukan secara online agar persetujuan lokasi cepat diproses oleh panitia KKLP.

- Terdapat saran lokasi KKLP untuk memudahkan mahasiswa mendapatkan lokasi yang sesuai dengan bidangnya. (Lokasi KKLP yang di sarankan telah kerja sama dengan kampus)

- Mengintegrasikan sistem pengelolaan data KKLP dengan Sistem Informasi Akademik STMIK KHARISMA.

- Pengembangan sistem menggunakan konsep MVC untuk memudahkan pembagian antara tampilan aplikasi, model data, dan navigasi aplikasi.

\subsection{Kebutuhan Fungsional}

Dari sistem yang akan dikembangkan oleh penulis, terdapat beberapa fitur-fitur yang akan ada dalam sistem ini, yaitu:

- Sistem mampu mendata anggota kelompok KKLP di sisi mahasiswa.

- Sistem mampu mendata lokasi KKLP mahasiswa.

- Sistem mampu memberikan informasi Pembimbing ke mahasiswa.

- Sistem mampu memberikan informasi jadwal ujian ke mahasiswa.

- Sistem dapat mendata pembimbing yang diinput oleh panitia.

- Jadwal dan penguji ujian KKLP (Panitia).

- Rekomendasi lokasi (Panitia).

\subsection{Kebutuhan Non Fungsional}

Dari sistem yang akan dikembangkan oleh penulis, terdapat beberapa kebutuhan yang dibutuhkan dalam pengembangannya, diantaranya:

- Laptop / PC Komputer untuk pengembangan aplikasi dan uji coba aplikasi.

- Software untung mengembangkan aplikasi website seperti dreamweaver, notepad++, dan sublime text.

- Browser seperti firefox dan google chrome untuk menguji coba aplikasi.

\subsection{Rancangan Use Case Diagram}

Use case adalah kegiatan atau urutan interaksi yang saling berkaitan antara sistem dan aktor. Use case bekerja dengan cara mendeskripsikan tipe interaksi antara user sebuah sistem dengan sistemnya sendiri melalui sebuah cerita bagaimana sebuah sistem dipakai. Use case juga digunakan untuk membentuk perilaku (behaviour) sistem yang akan dibuat. Sebuah use case menggambarkan sebuah interkasi antara pengguna (aktor) dengan sistem yang ada.[2]

Tujuan dari use case itu sendiri adalah untuk memetakkan kebutuhan sistem, merepresentasikan interaksi pengguna terhadap sistem, dan untuk mengetahui kebutuhan diluar sistem. 


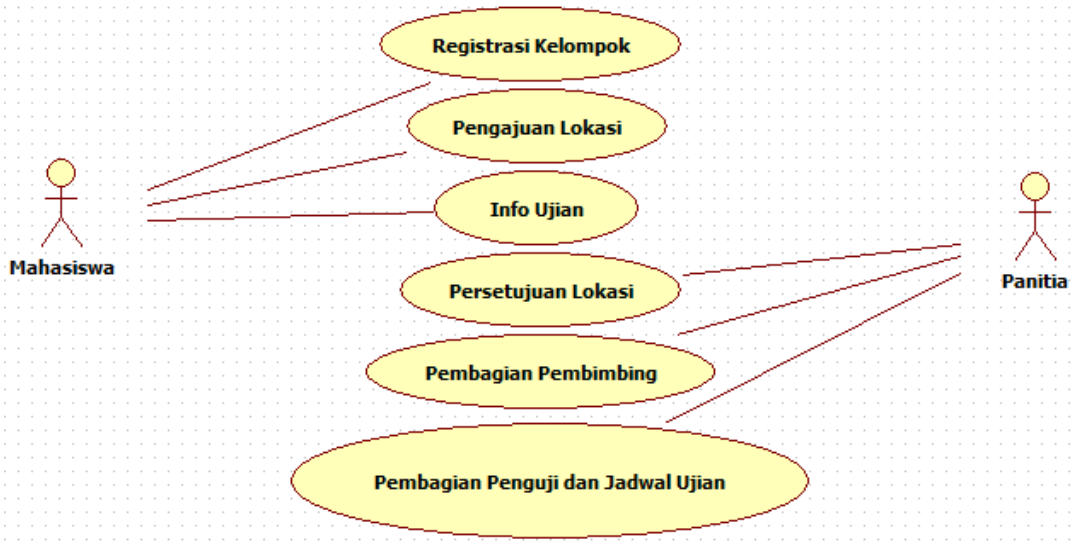

Gambar 2. Use Case Diagram

- Case registrasi kelompok, cese ini akan berhubungan dengan mahasiswa dan berfungsi untuk registrasi kelompok KKLP.

- Case input form pengajuan, case ini akan aktif setelah mahasiswa sudah memiliki kelompok dan mahasiswa dapat mengisi pengajuan lokasi KKLP pada form pengajuan.

- Case informasi pembimbing, dalam case ini mahasiswa dapat mengetahui nama pembimbing kelompok KKLP.

- Case jadwal ujian, dalam case ini berfungsi untuk memberitahukan jadwal ujian KKLP.

- Case pembagian pembimbing, case ini berfungsi untuk membagi pembimbing. Pembagian pembimbing di case ini akan diinput oleh panitia KKLP.

- Case jadwal dan penguji ujian KKLP, dalam case ini panitia akan menginput jadwal serta penguji untuk ujian KKLP. Yang akan terhubung pada case jadwal ujian.

- Case input rekomendasi lokasi, case ini berfungsi untuk mendata lokasi KKLP yang di sarankan oleh pihak kampus.

\subsection{Entity Relationship Diagram (ERD)}

Pengertian dari ERD (Entity Relationship Diagram) adalah suatu model untuk menjelaskan hubungan antar data dalam basis data berdasarkan objek-objek dasar data yang mempunyai hubungan antar relasi. ERD untuk memodelkan struktur data dan hubungan antar data, untuk menggambarkannya digunakan beberapa notasi dan simbol.[4]

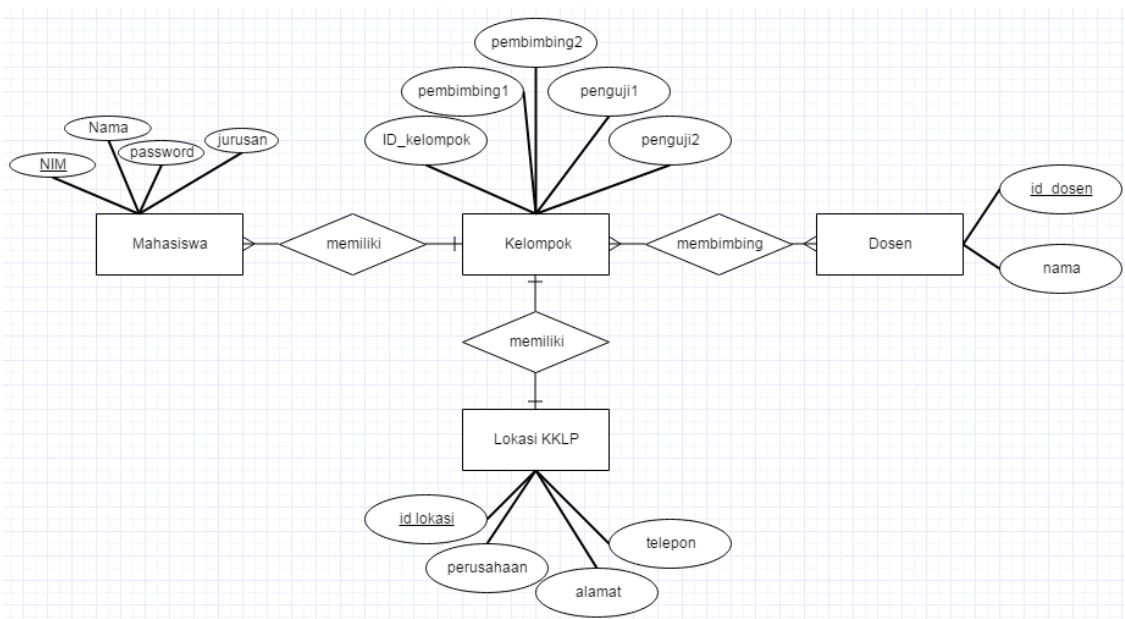

Gambar 3. Rancangan ERD

Entitas utama dalam aplikasi ini terdiri atas Mahasiswa, Kelompok, Dosen, dan Lokasi KKLP. Entitas Mahasiswa digunakan untuk mencatat data-data mahasiswa peserta KKLP yang melakukan registrasi, kemudian dari data mahasiswa tersebut akan terbentuk kelompok-kelompok mahasiswa dimana setiap kelompok, memiliki maksimal 3 (tiga) orang mahasiswa yang direkam kedalam entitas Kelompok 
Dari data kelompok mahasiswa yang terbentuk akan menentukan lokasi pelaksanaan KKLP. Lokasi bisa di pilih dari daftar lokasi yang sudah pernah ada berdasarkan rating atau peringkat yang baik, atau bisa dengan memasukkan lokasi yang baru. Data lokasi tersebut akan terekam kedalam entitas Lokasi KKLP.

Data Entitas Dosen digunakan untuk menentukan pembimbing yang terdiri atas 2 orang dosen untuk setiap kelompok mahasiswa yang telah terbentuk dan mempunyai lokasi pelaksanaan KKLP.

\subsection{Rancangan Arsitektur Framework Codelgniter}

Codelgniter merupakan salah satu dari sekian banyak framework PHP yang ada. Codelgniter dikembangkan oleh Rick Ellis. Tujuan dari pembuatan framework Codelgniter ini menurut user manualnya adalah untuk menghasilkan framework yang akan dapat digunakan untuk pengembangan proyek pembuatan website secara lebih cepat dibandingkan dengan pembuatan website dengan cara koding secara manual, dengan menyediakan banyak sekali pustaka yang dibutuhkan dalam pembuatan website, dengan antarmuka yang sederhana dan struktur logika untuk mengakses pustaka yang dibutuhkan. Codelgniter membiarkan kita untuk memfokuskan diri pada pembuatan website dengan meminimalkan pembuatan kode untuk berbagai tujuan pembuatan website.[1]

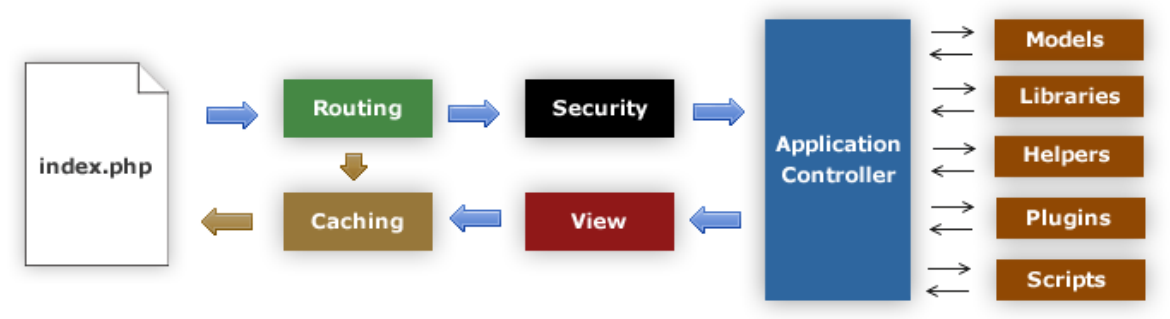

Gambar 4. Arsitektur Codelgniter

- File index.php berfungsi sebagai front controller, menginisialisasi resource utama yang dibutuhkan untuk menjalankan Codelgniter.

- Router memeriksa HTTP request untuk menentukan apa yang harus dilakukan dengan itu.

- Jika file cache ada, dikirim langsung ke browser, melewati eksekusi sistem normal.

- Keamanan. Sebelum controller aplikasi dimuat, HTTP request dan setiap data pengguna yang di submit disaring terlebih dahulu untuk keamanan.

- Controller memuat model, library utama, helper, dan setiap resource lainnya yang diperlukan untuk memproses permintaan khusus.

- View di render kemudian dikirim ke web browser agar dapat dilihat. Jika caching diaktifkan, view di cache terlebih dahulu sehingga pada permintaan berikutnya dapat dilayani.

Arsitektur yang terdapat dalam pengembangan sistem:

a. Pada Model terdapat : model user, model ujian, model persetujuan, model pembimbing, model lokasi, model login, model kelompok. Dimana pada model terletak alur database dari sistem

b. Pada View terdapat: view register kelompok, view register lokasi, view ujian, view persetujuan, view pembimbing, view penguji. Dimana pada view terletak tampilan interface yang di munculkan ke user.

c. Pada Controller terdapat: controller mahasiswa, controller dosen. Dimana dalam controller menghubungkan view dan model yang sudah di buat.

\subsection{Pengujian Sistem}

Metode pengujian yang digunakan pada penelitian ini adalah metode pengujian black box. Pengujian black box berfokus pada spesifikasi fungsional dari aplikasi, tester dapat mendefinisikan kumpulan kondisi input dan melakukan pengetesan pada spesifikasi funsional aplikasi. Apabila sistem dari aplikasi memberikan hasil yang tidak sesuai, berarti terdapat kesalahan pada sistem dari aplikasi. Krieria yang menjadi tolak ukur keberhasilan sistem adalah apabila sistem dapat memberikan output yang sesuai dengan alur aplikasi.[2]

Beberapa contoh dari hasil pengujian:

- Pengujian login 


\section{ILKOM Jurnal IImiah Volume 9 Nomor 2 Agustus 2017}

Data inputan terdiri atas NIM/nama user, dimana jika NIM/nama user ditemukan didalam database maka akan menampilkan halaman selanjutnya, yaitu jika login sebagai mahasiswa dengan memasukkan NIM maka akan menampilkan halaman utama dari mahasiswa tersebut, jika login dengan memasukkan username maka akan menampilkan halaman utama sebagai panitia atau administrator. Proses dapat dilihat pada Gambar 5, Gambar 6, dan Gambar 7

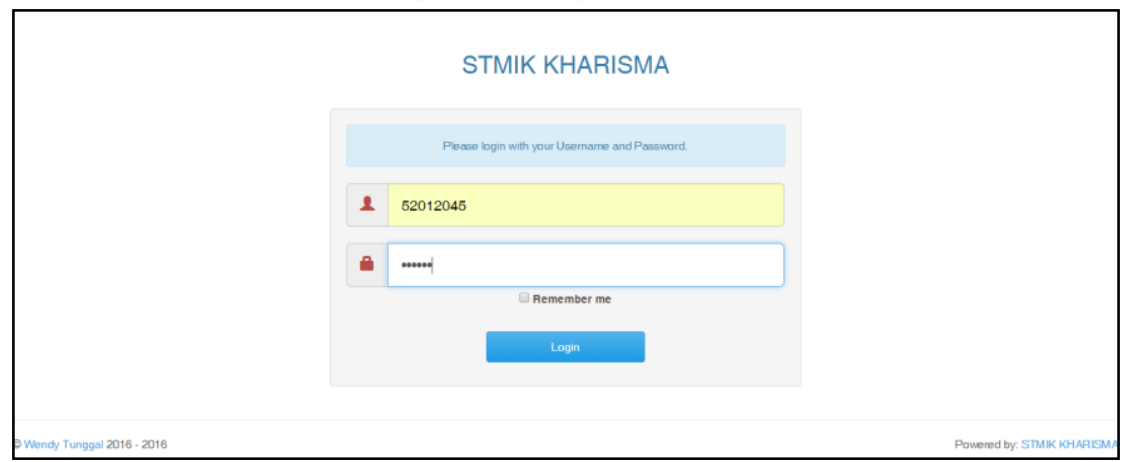

Gambar 5. Halaman Login NIM/nama user

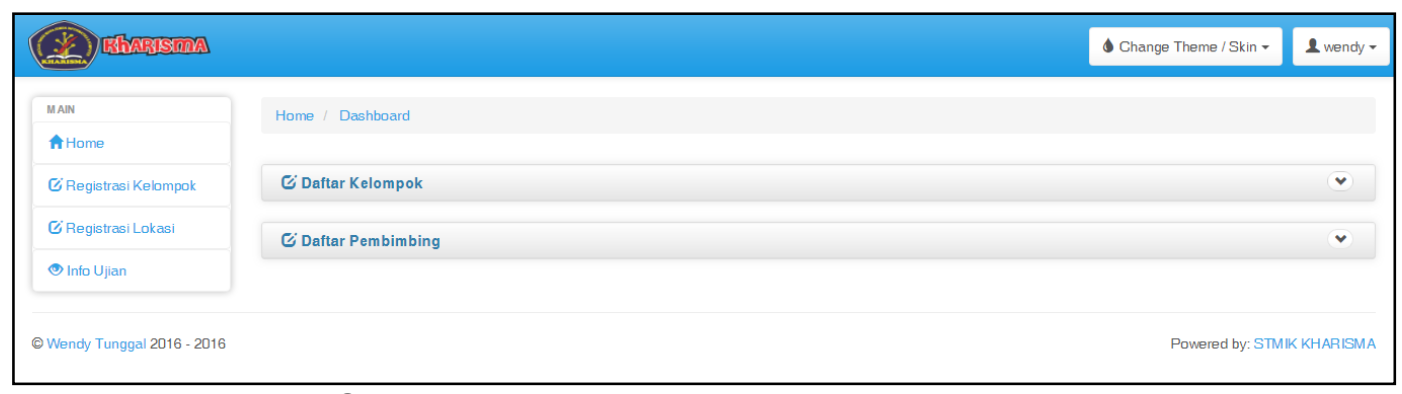

Gambar 6. Halaman utama login sebagai mahasiswa

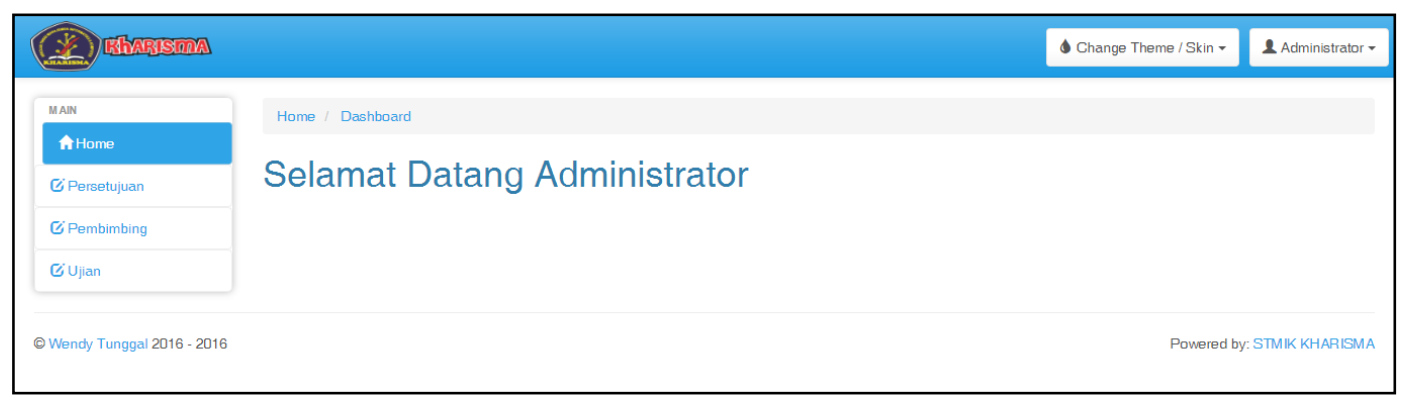

Gambar 7. Halaman utama login sebagai Panitia/Administrator

- Pengujian registrasi kelompok

Jika mahasiswa belum memiliki kelompok, maka tombol request kelompok akan muncul sehingga mahasiswa tersebut bisa membentuk kelompok yang baru. Jika mahasiswa sudah memiliki kelompok, maka tombol request anggota akan muncul untuk bisa menginput mahasiswa yang tergabung ke dalam kelompok tersebut. Proses dari pengujian registrasi kelompok dapat dilihat pada Gambar 8, Gambar 9, dan Gambar 10. 


\section{ILKOM Jurnal Ilmiah Volume 9 Nomor 2 Agustus 2017}

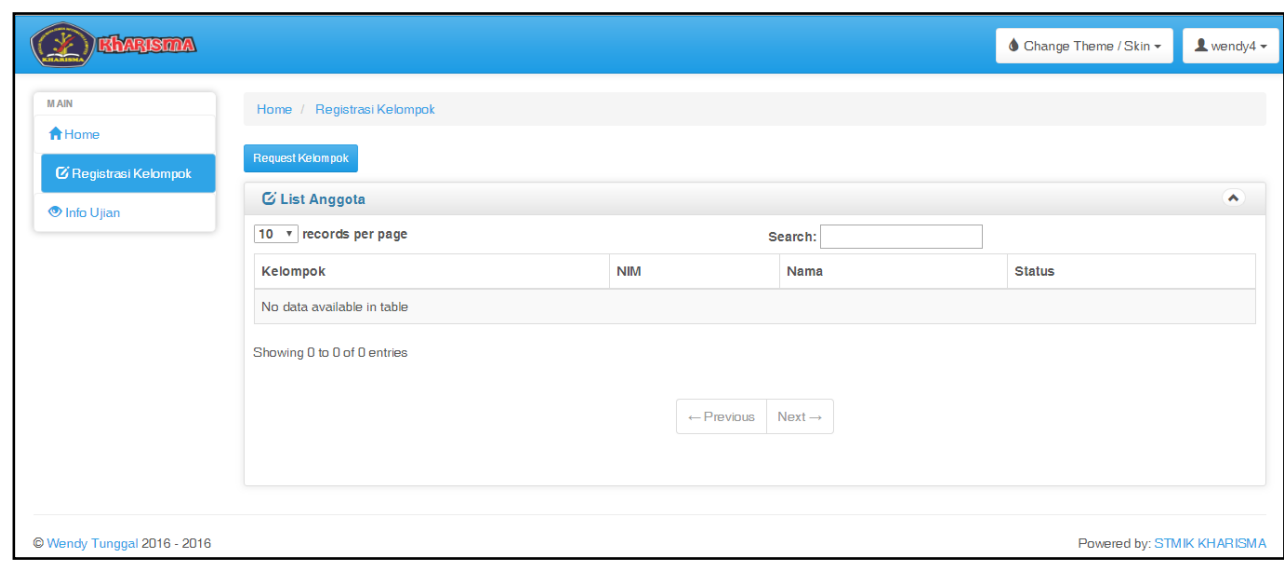

Gambar 8. Tampilan awal untuk registrasi kelompok

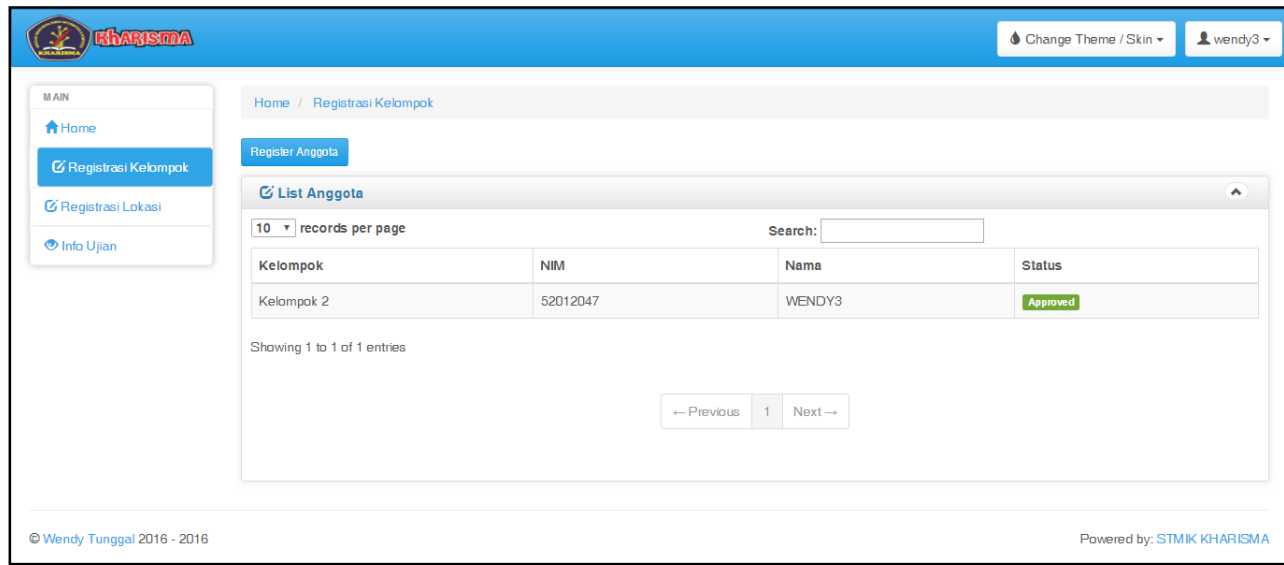

Gambar 9. Tampilan setelah memiliki kelompok

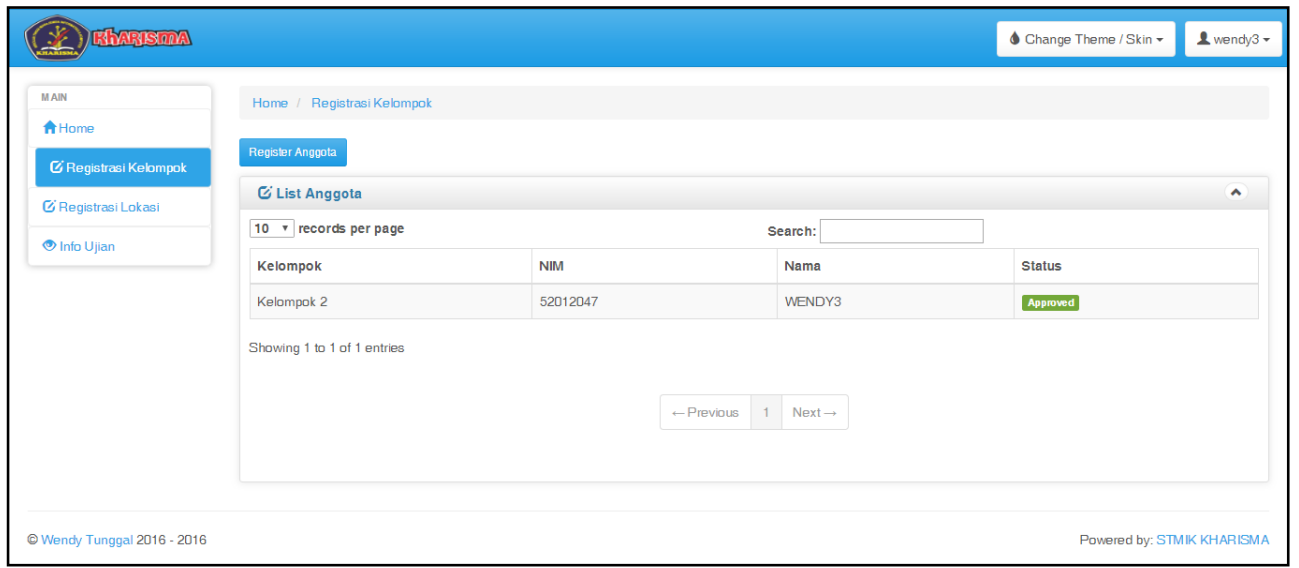

Gambar 10. Tampilan untuk menambah anggota kelompok

- Pengujian register lokasi

Data inputan terdiri atas nama perusahaan/instansi, alamat, sebutan pimpinan, dan nomor telepon perusahaan/instansi. Lokasi KKLP bisa di input baru dan juga bisa di pilih dari daftar lokasi yang sudah pernah tersimpan sebelumnya. Proses dari pengujian registrasi lokasi KKLP dapat dilihat pada Gambar 11, Gambar 12, dan Gambar 13. 


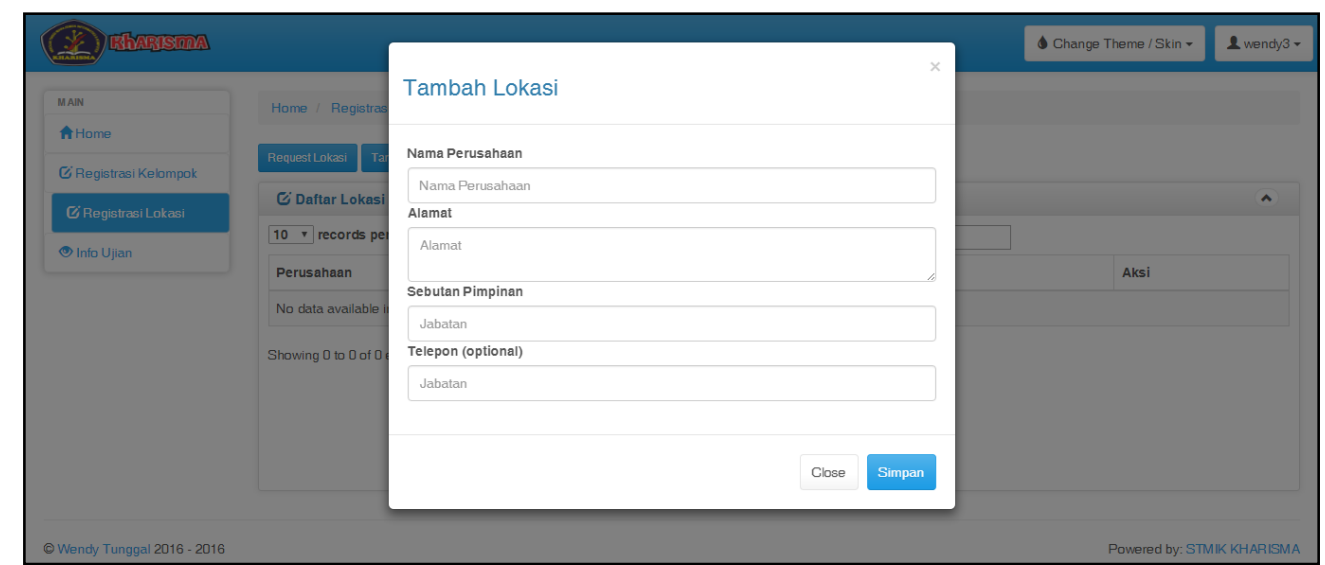

Gambar 11. Tampilan untuk menambah lokasi KKLP yang baru

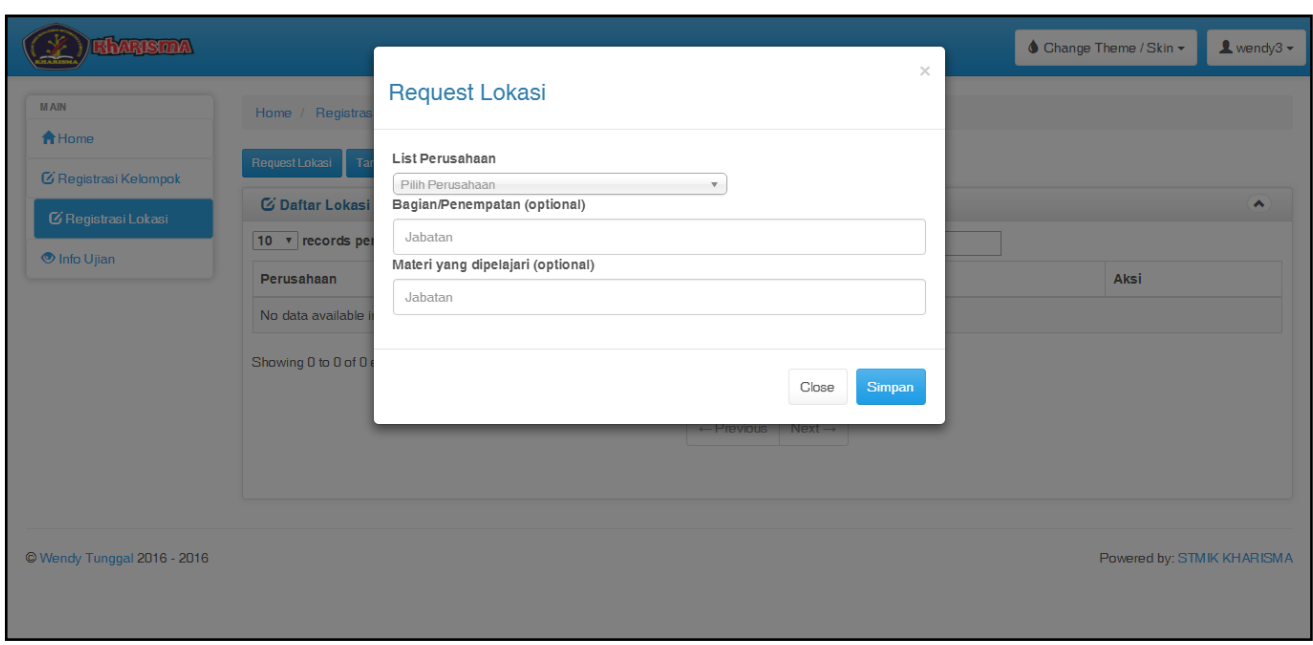

Gambar 12. Tampilan untuk memilih lokasi yang sudah ada sebelumnya.

\section{Kesimpulan dan saran}

Penulis telah berhasil merancang dan membangun sebuah Sistem Komputerisasi Pengelolaan Data KKLP Menggunakan Framework Codelgniter pada STMIK Kharisma Makassar. Aplikasi yang di buat dapat membantu baik pihak panitia pelaksana maupun mahasiswa dalam proses pelaksanaan KKLP. Pemanfaatan Framework codelgniter yang menggunakan pendekatan MVC (Model, View, Controller) yaitu metode pengembangan aplikasi PHP yang memisahkan antara data logic (Model) dengan presentation logic (Controller) membuat pengembangan aplikasi dapat menjadi lebih terstruktur.

Keunggulan model pendekatan pengembangan software dengan metode waterfall adalah pencerminan kepraktisan rekayasa, yang membuat kualitas software tetap terjaga karena pengembangannya yang terstruktur dan terawasi. Disisi lain model ini merupakan jenis model yang bersifat dokumen lengkap, sehingga proses pemeliharaan dapat dilakukan dengan mudah.

\section{Daftar Pustaka}

[1] Indrianto, A. M. (2010). Penerapan Codeigniter Framework Dalam Perkembangan Sistem Informasi Sidang Keliling. Jakarta: UIN.

[2] Jogiyanto, H. (2008). Analisis dan Desain Sistem. Yogyakarta: Andi.

[3] Kusrini. (2007). Strategi Perancangan dan Pengelolaan Basis Data. Yogyakarta: Andi.

[4] Tocharman, M. (2005). Magang Kewirausahaan pada Industri Keramik Sebagai Model Pembelajaran Kolaborasi dalam Meningkatkan Kompetensi Akademis Mahasiswa. 